\title{
Vulvar Soft Tissue Neoplasm
}

National Cancer Institute

\section{Source}

National Cancer Institute. Vulvar Soft Tissue Neoplasm. NCI Thesaurus. Code C40316.

A benign or malignant mesenchymal neoplasm of the vulva. Representative examples

include leiomyoma, cellular angiofibroma, ang iomyxoma, leiomyosarcoma, liposarcoma, and childhood botryoid-type embryonal rhabdomyosarcoma. 